\title{
REALITAS PERJAMUAN KHONG GUAN ADALAH REALITAS KITA
}

\section{GENERAL SOCIAL CONSTRUCTION IN ILLUSTRATION OF PERJAMUAN KHONG GUAN}

\author{
Liana Shinta Dewi $^{1 *}$, M. Daniel Fahmi Rizal' ${ }^{2}$, M. Iqbal Khoirunnahya ${ }^{3}$ \\ Pendidikan Bahasa dan Sastra Indonesia, Universitas Tidar, Indonesia ${ }^{1,2,3}$ \\ lianashinta@untidar.ac.id ${ }^{1}$, danielfahm@gmail.com ${ }^{2}$, \\ muhammadiqbalkhoirunnahya@ gmail.com ${ }^{3}$ \\ *penulis korespondensi
}

\begin{tabular}{ll}
\hline Info Artikel & ABSTRAK \\
\hline Sejarah artikel: & Tujuan penelitian ini adalah membahas topik pembicaraan dan permainan \\
Diterima: & bahasa yang ada di dalam kumpulan sajak Perjamuan Khong Guan karya \\
25 Oktober 2021 & Joko Pinurbo. Konsep dan metode yang digunakan dalam penelitian ini \\
Direvisi: & adalah hermeneutika. Hasil analisis menunjukkan bahwa pengarang \\
12 Desember 2021 & memilih topik-topik yang relatable dengan masyarakat, misalnya, \\
Disetujui: & religiusitas, keterasingan sosial, dan cinta dan kerinduan. Terkait bahasa, \\
10 Januari 2022 & pemilihan bahasa-bahasa yang sederhana dan kontekstual oleh pengarang \\
& justru untuk membuat maknanya mudah dipahami dan bisa dengan mudah \\
Kata kunci: & direfleksikan kembali oleh masyarakat pembacanya.
\end{tabular}

joko pinurbo, khong

guan, hermeneutika,

cinta, religiusitas

\begin{tabular}{ll}
\hline Article Info & ABSTRACT \\
\hline Article history: & The aims of this study are discussing the topic converstion and how the \\
Received: & language play in the book of poem collection, Perjamuan Khong Guan \\
25 October 2021 & written by Joko Pinurbo. Concept and method used in this study is \\
Revised: & hermeneutics.The study shows that the author chose topics that are relatable \\
12 December 2021 & to society i.e., religiosity, social alienation, and love and longing. From the \\
Accepted: & language perspective, the author chose simple and contextual languages \\
10 January 2022 & precisely to make the meaning easily to be understood and be reflected by \\
& the reader.
\end{tabular}

Keyword:

joko pinurbo, khong

guan, hermeneutics,

love, religiosity

\section{PENDAHULUAN}

Konflik dalam masyarakat ini pada dasarnyaa bisa diuraikan bila masing-masing individu menahan diri dan melakukan refleksi terhadap segala sember kekacauan tersebut. Joko Pinurbo meyampaikan bahwa sastra menyediakan ruang tersebut. Melalui sastra, masyarakat dilatih untuk mengembangkan imajinasi dan rasa empati (Pinurbo, 2019). Sastra memberikan ruang untuk mendapatkan edukasi mengenai hal positif tanpa merasa digurui. Gagasan semacam ini 
kemudian diwujudkan oleh Pinurbo dalam rangkaian sajak yang terhimpun dalam kumpulan sajak Perjamuan Khong Guan (selanjutnya disebut $P K G$ ) (Pinurbo, 2020).

Sastra mengenal istilah litentia poetica. Hal ini seringkali membuat bahasa sastra diidentikan dengan bahasa yang sulit untuk dipahami. Hal ini akan terlihat makin-makin dalam genre puisi. Bahkan, dari tulisan Prie G. S. (Prie, 2004) diketahui bahwa sastrawan sekelas Chairil Anwar pernah menyebutkan kredo "Yang bukan penyair jangan ikut ambil bagian". Pernyataan itu menegaskan sifat eksklusif dalam bahasa karya sastra, terlebih puisi. Secara tidak langsung, sifat bahasa sastra yang cenderung eksklusif ini juga membuat tema-tema yang dibahas di dalam karya sastra menjadi terkesan eksklusif dan sulit dipahami mengingat pesan disampaikan melalui bahasa.

Gagasan semacam ini kemudian dipatahkan oleh karya-karya yang ditulis oleh Joko Pinurbo, termasuk karya $P K G$. Dalam sebuah seminar nasional mengenai sikap partisan dalam karya sastra, Joko Pinurbo menyampaikan mengenai kekuatan puisi dan bahasanya untuk menyikapi kehidupan. Menurutnya, hidup kekacauan dalam hidup bisa diuraikan dalam puisi, sastra secara umum. Lebih lanjut, dia menyampaikan kekagumannya terhadap daya puitik bahasa Indonesia yang menurutnya bisa menguraikan absurditas dan kompleksitas kehidupan (Pinurbo, 2019).

Pendapat Joko Pinurbo di atas menyiratkan bahwa puisi dan bahasa Indonesia mampu membuat kompleksitas dan kebsurdan realitas kehidupan menjadi lebih sederhana dan terbaca. Hal ini, kemudian, tampak dalam bahasa yang digunakan dan tema yang diangkat oleh Joko Pinurbo dalam kumpulan puisi $P K G$. Dia memainkan bahasa Indonesia sedemikian rupa sehingga muncul estetikanya tersendiri meskipun tampaknya sederhana. Berkaitan dengan tema, Joko Pinurbo mengangkat tema-tema yang relate dengan kehidupan masyarakat secara umum. Permainan bahasa Indonesia dan tema yang relatable dengan masyarakat ini menjadi hal yang cukup dominan dalam kumpulan puisi $P K G$. Akan tetapi, permainan bahasa yang terkesan sederhana dan tema yang tampak ringan ini justru membuat sajak-sajaknya memberikan ruang bagi pembaca untuk berkontemplasi dan merefleksikan kembali realitas yang dijalani sehar-hari. Hal inilah yang akan menjadi topik pembicaraan dalam penelitian ini: Bagaimana permainan bahasa Indonesia dan kesederhanaan tema dalam kumpulan puisi $P K G$ tanpa kehilangan kedalamannya?

Untuk menganalis penyampaian tema-tema tadi sehingga menjadi tematema yang terkait dengan kehidupan masyarakat digunakan model pembacaan hermeneutika. Menurut Zuchidi dan Afifah, hermeneutika adalah "teori interpretasi"(Zuchdi \& Afifah, 2021). Pendapat ini sama dengan pendapat Ricoeur bahwa hermeneutik adalah piranti, teori yang digunakan untuk memahami teks. Lebih lanjut, Ricoeur menjelaskan bahwa kata-kata (dalam hal ini diterjemahkan dalam teks) sangat mungkin memiliki makna lebih dari satu saat ia dikaitkan dengan konteks yang melingkupinya. Ricoeur menyebut ini sebagai polisemi. Sementara itu, upaya untuk memahami maksud teks yang terlingkupi konteks tadi disebut dengan interpretasi (Ricoeur, 2021). 
Hermeneutika

harus memperhatikan banyak horison harapan yaitu horison harapan teks, pengarang, dan pembaca yang muaranya pada rekonstruksi dan reproduksi makna teks (Lutfi, 2007). Hal ini menegaskan bahwa konteks suatu teks menjadi hal yang penting dalam sebuah upaya penafsiran meneurut hermeneutika. Selain itu, hal ini juga berarti bahwa makna teks akan terus terbuka dan memungkinkan untuk terus ditafsirkan.

Ada beberapa penelitian yang membahas karya $P K G$. Mengingat $P K G$ baru diterbitkan tahun 2020, penelitian yang dilakukan pun umumnya ada di rentang 2020-2021. Penelitian yang dilakukan pada 2020 dilakukan oleh Ari Ambarwati dkk (Ambarwati et al., 2020) dengan topik pembahasan metafora gastronomi pada sajak $P K G$, penelitian Mukodas dan Wildan F. Mubarok (Mukodas \& Mubarock, 2019) dengan topik pembahasan humor di dalam kumpulan puisi $P K G$, dan Shindy Lie (Lie, 2020) dengan topik pembahasan perancangan buku. Adapun penelitian yang dilakukan pada tahun 2021 adalah penelitian Febriyanto Yoko (Yoko, 2021) tentang citraan pada kumpulan puisi $P K G$, penelitian Dwi Rizkya Firdaus (Firdaus, 2021) tentang struktur batin dan fisik dalam $P K G$, penelitian Analis Dwi Azizah (Azizah, 2021) tentang kritik sosial dalam $P K G$ menggunakan konsep Roland Barthes.

Secara umum, penelitian-peneitian tersebut berbeda dengan penelitian yang akan dilakukan ini. Penelitian ini fokus pada analisis teks sajak-sajak dalam kumpulan puisi $P K G$ dengan konsep hermeneutika. Topik ini tidak digunakan dalam penelitian-penelitian sebelumnya. Penelitian yang hampir bersinggungan adalah penelitian yang dilakukan oleh Febriyanto Yoko dan Analis Dwi Azizah. Akan tetapi, penelitian Yoko fokus pada citraan yang digunakan dalam kumpulan sajak Perjamuan Khong Guan, sementara Azizah fokus pada analisis tanda dengan menggunakan konsep yang digagas oleh Roland Barthes.

\section{METODE}

Penelitian ini menggunakan pendekatan kualitatif. Sugiyono menegaskan bahwa dalam penelitian kualitatif, peneliti berlaku sebagai instrumen penting untuk menafsirkan data-data (Sugiyono, 2010). Dapat dikatakan juga bahwa peneliti adalah penafsir data dalam penelitian ini. Adapun data dalam penelitian ini adalah seluruh seluruh teks sajak yang dihimpun dalam kumpulan sajak $P K G$. Sumber data dalam peneltian ini adalah buku kumpulan sajak $P K G$ karya Joko pinurbo yang diterbitkan pada tahun 2020.

Dari pembacaannya terhadap karya-karya Paul Ricouer, Abdul Hadi mengungkapkan bahwa metode penelitian menggunakan konsep hermeneutika terdiri atas beberapa tahapan. Pertama, penelitian-dalam hal ini bertindak sebagai penafsirmembaca teks dengan menggunakan imajinasi. Kedua, peneliti menentukan tanda-tanda penting yang ada di dalam teks untuk mengungkap makna terdalamnya. Ketiga, peneliti mengaitkan makna dan gagasan di dalam teks dengan kenyataan nonbahasa di luar teks. Poin ketiga dapat dipahami sebagai upaya untuk mengaitkan kenyataan di dalam teks dengan kenyataan di luar teks (Hadi W.M., 2014). Bila prosedur itu dilakukan untuk menganalisis kumpulan puisi $P K G$, hal yang bisa dilakukan adalah: 1. Mengumpulkan 
data dengan membaca sajak-sajak dalam $P K G$ dengan menggunakan imajinasi; 2. Mencatat simbol-simbol penting dalam sajak-sajak $P K G$ untuk menentukan maknanya; 3. Mengaitkan makna-makna simbol tadi dengan kenyataan yang ada di luar teks $P K G$.

\section{HASIL DAN PEMBAHASAN}

Seperti yang diungkapkan di bagian pendahuluan, ada dua hal menonjol yang muncul dalam pembacaan sekilas kumpulan puisi Perjamuan Khong Guan. Yang pertama, tema yang relatable dengan kehidupan masyarakat. Yang kedua, permainan bahasa Indonesia. Gabungan keduanya tidak menjauhkan makna, tetapi justru memperdalam makna dan bersifat kontemplatif.

\section{Kenyataan Bersama}

Buku kumpulan puisi $P K G$ disusun dengan beberapa sub-judul Kaleng. Ada empat Kaleng di dalam kumpulan puisi ini yaitu Kaleng Satu, Kaleng Dua, Kaleng Tiga, dan Kaleng Empat. Topik-topik yang dibicarakan dalam tiap kalengnya beragam dan bisa digolongkan ke dalam beberapa kategori yaitu religiusitas-refleksi komitmen keberagaamaan individu yang tercermin dalam sikap maupun perilaku (Johnson et al., 2001); berkaitan dengan nilai-nilai ketuhanan (Anasrullah, 2018)-ketarsingan sosial, dan cinta dan kerinduan. Terkait dengan topik-topik itu, Pinurbo menggambarkan permasalahan yang umumnya terjadi di dalam masyarakat. Sebagai contoh, terkait dengan religiusitas, Pinurbo membidik religiusitas manusia modern yang acapkali merasa tidak cukup dan takut kehilangan hal-hal yang telah dimilikinya, merasa kehilangan makna religiustias dalam keriuhan teknologi, dan kerukunan umat beragama.

Pada sajak "Belum" digambarkan kontradiksi antara orang yang kehilangan dompet tetapi masih bisa bersyukur dengan orang yang bahkan belum memiliki dompet dan isinya tetapi takut kehilangannya. Hal ini adalah realitas yang lazim ditemui dalam masyarakat. Banyak di antara manusia yang merasa takut kehilangan sesuatu yang bahkan belum dimilikinya. Puisi ini menggambarkan realitas itu sebagai kewajaran dengan kata "Amin?". Aamiin yang diakhiri dengan tanda tanya di sana dapat dimaknai sebagai sikap puisi ini mempertanyakan sikap orang yang takut kehilangan tadi: Apakah kamu benar-benar bersyukur?

Sajak "Malam Virtual" menggambarkan sepinya religiusitas di tengah gegap-gempita teknologi yang bersifat maya, "virtual". Si Aku tidak bisa menemukan begitu saja Natal-nya, tetapi harus mencari karena Natal dan maknanya telah tertutupi oleh keriuhan teknologi yang serba digital. Hal ini pun jamak terjadi dalam kehidupan religius masyarakat saat ini. Sebagai contoh, saat Lebaran, dengan mudahnya seseorang mengirimkan pesan melalui platform berkirim dengan isi pesan yang sudah diatur template: satu pesan dikirimkan untuk banyak orang. Oleh Si Penerima, pesan ini pun dianggap biasa saja dan kemudian ia teruskan pada orang lain. Esensi "mohon maaf lahir batin" pada pesan menjadi hanya sekedar tulisan saja. Hal ini menunjukkan bahwa teknologi membuat seseorang mudah menyebarkan gagasan-gagasan yang berkaitan dengan religiusitas, tetapi pada saat yang sama, nilai religiusitas itu sendiri tereduksi. 
Sajak “Agama Khong Guan” lebih mirip sebagai pengharapan dan doa atas realitas keagaamaan yang terjadi di masyarakat Indonesia, masyarakat tempat lahirnya kumpulan sajak $P K G$. Masyarakat hiruk-pikuk memperdebatkan agama masingmasing. Sebagai catatan, secara resmi, negara Indonesia mengakui enam agama resmi: Islam, Kristen, Katolik, Hindhu, Budha, dan Khonghucu. Indonesia juga memiliki lebih dari satu aliran kepercayaan. Kemajemukan agama dan keyakinan ini acapkali membuat gesekan-gesekan dalam masyarakat. Gesekan ini makin menguat dengan menguatnya penggunaan politik identitas dalam kehidupan politik Indonesia sehingga sebagian masyarakat, alih-alih melihat hal-hal yang sama dalam perbedaan pandangan keagamaan tersebut, justru memperuncing perbedaan. Akibat jauhnya, kondisi keberagamaan di Indonesia seolah makin terpecah-belah. Dalam situasi semacam itu, puisi ini seperti sebuah nada pengharapan agar semua agama berbahagia dalam Kaleng Khong Guan, Indonesia: rukun kembali.

$P K G$ juga membahas masalah sosial dan keterasingan individu. Kaleng Pertama adalah bagian yang cukup banyak membicarakan masalah sosial. $P K G$ mengangkat topik banjir, keterbatasan fasilitas rumah sakit, kegagapan manusia dalam menghadapi teknologi sehingga terjebak dalam hoaks dan sifat narsis. Hal ini, misalnya, dapat dilihat dalam sajaksajak"Menunggu Kamar Kosong di Rumah Sakit", "Fotoku Abadi", "Markipul", "Mudik Khong Guan".

Sajak "Menunggu Kamar Kosong" ditulis tahun 2018, tetapi masih sangat relevan menggambarkan situasi masyarakat Indonesia dua tahun belakangan yang harus menghadapi pandemi Covid-19. Masyarakat seluruh lapisan dipapari kenyataan seperti yang digambarkan dalam sajak di atas bahwa sakit memang sangat rumit. Selama menghadapi ledakan kasus Covid-19, masyarakat Indonesia yang membutuhkan rumah sakit seolah "Menunggui Kamar Kosong di Rumah Sakit".

Sajak "Fotoku Abadi", "Patah Hati", dan "Kembang Susu" menggambarkan manusia di tengah pusaran teknologi. Hal ini sangat relevan dengan realitas kehidupan masyarakat saat ini. Media sosial membuat dan semua fitur unggah gambar dan unggah berita membuat seseorang leluasa membagikan gambar dirinya atau berita apapun. Bahkan, tidak jarang, manusia mengumbar rahasianya sendiri di media sosial. Hal ini sangat memungkinkan manusia terjebak dalam sifat narsistik, haus pengakuan, bahkan tidak jarang membuat manusia terjebak dalam masalah hukum.

Sajak "Kembang Susu" juga dapat dimaknai sebagai sebuah pengingat dan imbauan. Menurut sajak ini, manusia tidak pernah dilahirkan untuk menjadi penyebar berita bohong dan menyebarkan amarah. Pada awalnya, bahasa yang dikenal oleh manusia adalah bahasa cinta. Oleh karena itu, manusia diajak untuk kembali ke dalam karakteristik itu: penuh cinta, tidak menjadi individu yang menyebarkan kebohonngan dan amarah.

Sementara itu, "Markipul", "Mudik Khong Guan", dan "Simbah Khong Guan" adalah contoh sajak yang menggambarkan keterasingan individu. Keterasingan ini disebabkan oleh banyak hal, di antaranya adalah teknologi, pekerjaan, usia, dan perpindahan tempat tinggal. Dalam 
"Markipul" digambarkan kerinduan seseorang akan rumah tetapi teknologi yang dalam sajak ini digambarkan dengan ponsel telah membuatnya gila sehingga rumahnya berpindah menjadi RSJ. Sementara dalam "Mudik Khong Guan" digambarkan kerinduan seseorang akan rumah dan kampung halamannya tetapi rumah dan kampung halamannya sudah tidak ada lagi. Sementara itu, "Simbah Khong Guan", ketarsingan disebabkan oleh usia. Hal ini berkelindan dengan kesepian yang digambarkan dalam"Mudik Khong Guan".

Hal ini juga relevan dengan kehidupan masyarakat Indonesia yang melakukan urbanisasi. Masyarakat dari desa atau daerah pinggiran berpindah ke daerah perkotaan karena berbagai alasan: sekolah, bekerja, atapun alasan lainnya. Kepergian mereka meninggalkan kampung halaman, orang-orang tua. Di sisi lain, tidak semua orang yang berurbanisasi kembali lagi kedaerah asalnya. Hal ini kekosongan di wilayah asal mereka, misalnya, kekosongan sumber daya manusia. Dampak lainnya, hal ini menimbulkan keterasingan baik bagi yang meninggalkan kampung halaman maupun yang ditinggalkan karena ada jarak ruang dan waktu antara individu yang melakukan urbanisasi dengan wilayah ataupun orang-orang yang tetap tinggal di daerah asalnya, pun sebaliknya. Keterasingan semacam ini pernah digambarkan secara apik oleh Ajip Rosidi dalam pengantar kumpulan puisinya yang berjudul Cari Muatan: Empat Kumpulan Sajak (Rosidi, 2017).

Pembicaraan mengenai cinta dan kerinduan dalam sajak ini muncul, misalnya, dalam sajak "Dari Jendela Pesawat", "Kopi Koplo", "Malam Minggu di Angkringan", "Masuk anging", "Rumah Tangga", "Anak
Buah". Cinta yang digambarkan dalam sajak-sajak tersebut adalah cinta yang jamak dialami oleh manusia pada umumnya. Sebagai contoh, dalam sajak "Dari Jendela Pesawat" digambarkan kekasih yang melepaskan kerinduannya di angkringan - sebuah warung tenda yang menjajakan makanan dan minuman dengan harga murah; nasi yang dijual di sana umumnya disebut nasi kucing. Percintaan semacam ini banyak ditemuai di kalangan mudamudia: dua orang jatuh cinta dan kemudian melepaskan rindu.

"Malam Minggu di Angkringan" menggambarkan cinta yang lebih universal yaitu cinta antara satu manusia pada manusia lainnya. Di dalamnya digambarkan mengenai tawaran seorang individu pada individu lainnya untuk bersandar pada dirinya di tengah hiruk-pikuk kehidupan yang meneyramkan - sajak ini menggunakan kata sangar. Cinta semacam ini juga cinta yang lazim ditemui dalam realitas keseharian. Di angkringan, orang asing pun biasa bertegur-sapa, membicarakan banyak hal. Hal ini mungkin terlihat remeh temeh, tetapi pembicaraan semacam itu adalah penghiburan di dalam masyarakat. Angkringan bisa dimaknai sebagai metafora ruang sosial yang lebih luas, misalnya, jamaah pengajian, kelompok karang taruna, atau komunitas-komunitas lainnya yang bisa memberikan ruang bagi individu untuk berbagi dengan individu lainnya.

\section{Bermain Kata, Memperdalam Makna}

Hal yang menonjol dari pembacaan sekilas sajak kumpulan sajak $P K G$ adalah penggunaan bahasabahasa yang secara jamak dikenal oleh masyarakat, bahasa keseharian. Diksisiksi yang dipilih untuk menyampaikan 
maksudnya pun diksi-diksi yang yang umum digunakan oleh masyarakat. Hal ini membuat sajak-sajaknya mampu membangkitkan memori kolektif masyarakat sehingga topik yang dibicarakan menjadi relateble dengan kehidupan masyarakat umum.

Dari judul, diksi yang menonjol adalah kata Khong Guan. Kata ini adalah kata yang familiar dalam masyarakat Indonesia. Awalnya, biskuit ini cukup mahal untuk kelas menengah ke bawah sehingga keberadaan biskuit ini di rumah-rumah masyarakat menandakan posisi sosial tertentu-kelas ekonomi atas. Yang berkembang kemudian, banyak masyarakat yang tidak mampu membeli biskuit ini menyimpan kaleng Khong Guan dan mengisinya dengan makanan tradisional alih-aling biskuit, misalnya, rengginang, peyek, kembang goyang. Fenomena ini menjadi komedi satire yang berkembang dalam masyarakat dan memori kolektif masyarakat Indonesia cukup mudah mengenali fenomena ini. Pemilihan diksi ini, kemudian, juga membuat masyarakat pembaca $P K G$ terhubung dengan topik-topik yang disampaikan di dalamnya.

Seperti yang telah diungkapkan sebelumnya, buku kumpulan puisi $P K G$ disusun dengan beberapa sub-judul Kaleng. Ada empat Kaleng di dalam kumpulan puisi ini yaitu Kaleng Satu, Kaleng Dua, Kaleng Tiga, dan Kaleng Empat. Pemilihan kata kaleng ini menunjukkan keterkaitannya dengan biskuit Khong Guan yang umumnya dikemas dalam kaleng berwarna merah. Kata kaleng sendiri cukup mudah untuk dipahami oleh banya orang karena nyaris semua penutur bahasa Indonesia mengerti makna ini. Akan tetapi, dalam satu kaleng biskuit Khong Guan, umumnya ada banyak jenis biskuit.
Bahkan, isi Khong Guan bisa juga peyek, rengginang, dan kembang goyang. Hal ini juga sama dengan Kaleng-Kaleng dalam kumpulan puisi ini yang tidak hanya terdiri atas satu rasa topik. Seperti yang diungkapkan sebelumnya, dalam kumpulan puisi ini ada topik mengenai religiusitas, cinta dan kerinduan, keterasingan sosial, dan cinta dan kerinduan.

Dalam pemilihan judul tiap sajaknya, Pinurbo memilih diksi-diski yang bahkan terdengar tidak puitis, misalnya, kata Wawancara Kerja, Belum, Gajian, Markipul (mari kita pulang), Datang Bulan, Minnah, Anak, Musik, Tidur untuk judul-judul sajaknya. Demikian halnya penggunaan perumpaan di dalam sajaknya. Pinurbo memilih kata kopi untuk menggambarkan rindu, punggung hangat dan liberal untuk menggambarakan rakyat, dingin perkasa untuk menggambarkan negara. Joko Pinurbo tidak segan menggunakan diksi kekinian untuk menggambarkan realitas sosial, misalnya deadline, ponsel, virtual, kredit rumah, iklan, mabuk agama. Meskipun demikian, diksi-diksi yang digunakan dalam $P K G$ cukup kuat untuk membuat pembaca merefleksikan ulang kenyataan yang tergambar di dalam sajak. Hal ini, misalnya, terlihat dalam sajak "Ninabobok".

\section{Nina bobok \\ dalam pelukan agama. \\ Kalau tidak bobok \\ dalam pelukan agama, \\ nanti digigit \\ negara neraka.}

Terbuai

Iklan masuk surga,

Nina lupa memeluk

gulingnya. 
Tak ada yang bisa

membangunkan Nina

yang sedang

mabok bobok

dalam pelukan

negara agama

selain ponselnya

yang tak beragama

(Ninabobok, 2018)

Sajak di atas memberikan gambaran yang kuat mengenai realitas keberagamaan masyarakat Indonesia dewasa ini. Sebagian masyarakat dengan mudah menghakimi cara beragama atau keyakinan individu lainnya. Bahkan, tidak jarang, bekal yang mereka gunakan untuk menghakimi pihak lain hanya didapatkan melalui artikel-artikel di dengan argumentasi yang masih lemah. Berkaitan dengan hal itu, muncul istilah mabuk agama yaitu istilah yang digunakan untuk menggambarkan kondisi individu yang membabi-butaseringkali judgemental - dalam menilai praktik keagamaan individu lainnya. Dalam sajak itu digambarkan bahwa orang yang mabuk agama sulit untuk dibangunkan. Pada kenyataannya, orang yang membabi-buta dalam menghakimi praktik keberagamaan individu lainnya memang sulit untuk diberi pemahaman, yang ilmiah sekalipun. Penggunaa diksi-diksi yang familiar dengan masyarakat di dalam sajak ini membuat pesan dalam sajak ini lebih kuat dan lebih terkoneksi dengan kehidupan sehari-hari masyarakat pembacanya.

Contoh sajak lain yang menggunakan kata-kata yang familiar dengan masyarakat adalah sajak "Hati Minnah".

\section{Batu di gunung,}

\section{Ombak di laut}

Bertemu di dada Minnah

(Hati Minnah, 2019)

Dalam sajak tersebut, nyaris tidak ada kata yang tidak digunakan dalam kehidupan sehari-hari masyarakat Indonesia. Akan tetapi, rangkaian kata-kata yang familiar di telinga masyarakat tersebut membuat efek yang cukup kuat dan dalam. Hal ini juga didukung gaya sajak yang menyerupai peribahasa "Asam di gunung, garam di laut, akhirnya bertemu di belanga." Peribahasa ini cukup kuat dalam memori masyarakat Indonesia.

Sajak tersebut menggambarkan dada Minnah yang sangat luas hingga mampu menampung batu dari gunung dan obak di laut. Karakteristik orang semacam ini adalah karakteristik yang diperlukan dalam realitas ke-Indonesiaan: orang yang mampu menerima segala perbedaan. Karena berkurangnya karakteristik lapang dada dalam diri masyarakat Indonesia, Indonesia mengalami masa seperti yang digambarkan dalam sajak "Ninabobok".

Pinurbo juga membolak-balik kata yang bunyinya sama tetapi maknanya berbeda. Hal ini misalnya terlihat dalam sajak "Demokrasi". Joko Pinurbo membolak-balik kata Sukir, Kursi, Sukri untuk menggambarkan rakyat, jabatan, dan pejabat yang memegang jabatan itu. Pada sajak "Datang Bulan" dibolak-balik kata jelata dan jelita. Pada sajak "Gajian" dibolak-balik kata iman dan amin.

Secara umum, permainan kata ini digunakan untuk menunjukkan opisisi. Dalam permainan kata Sukir dan Sukri terlihat oposisi antara rakyat dengan pejabat. Dalam permainan kata jelata dan jelita terlihat oposisi antara rakyat yang miskin dengan lampu- 
lampu jelita yang notabene nyaris tidak bisa dihasilkan oleh orang-orang jelata. Dalam permainan kata iman dan amin terlihat oposisi antara orang kaya dan miskin. Oposisi-oposisi dalam permainan kata ini menunjukkan bahwa permainan kata yang digunakan Joko Pinurbo memiliki efek puitis apabila kata-kata tersebut direfleksikan kembali.

Pada Kaleng Tiga, $P K G$ menggunakan kata Minnah untuk judul-judulnya. Dari pengucapannya, Minnah adalah sebuah nama yang lazim digunakan oleh masyarakat suku Jawa kelas menengah ke bawah. Minnah digambarkan lahir dari buku, lahir dari membaca. Hal ini terlihat dalam sajak "Lahirnya Minnah" yang menggambarkan pentingnya membaca. Membaca membuat seseorang tidak tergesa-gesa dan berpikir sebelum berbicara.

\section{PENUTUP}

Analisis terhadap sajak-sajak Joko Pinurbo menunjukkan bahwa teknik untuk menyampaikan konsep ketidakberlangsungan dalam puisi tidak selalu dengan kata yang rumit dan arkais. Puisi bisa menyimpan ketidakberlangsungannya dengan menggunakan kata-kata yang sederhana, familiar, dan mampu terkoneksi dengan memori kolektif masyarakat pembacanya. Gaya semacam ini akan membuat puisi memiliki daya jangkau yang lebih luas. Berbeda dengan penrnyataan Chairil bahwa sastra, puisi hanya untuk penyair, Pinurbo membuat puisi menjadi mungkin dan terjangkau untuk khalayak yang bahkan bukan penyair.

\section{UCAPAN TERIMA KASIH}

Terima kasih disampaikan pada LPPM-PMP Universitas Tidar,
Fakultas Keguruan dan Ilmu Pendidikan, Universitas Tidar, dan anggota penelitian yang telah memungkinkan terselesaikannya penelitian ini. Penulis senantiasa berharap bahwa dukungan-dukungan dari pihak terkait tidak hanya berhenti dalam penelitian ini, tetapi juga penelitian-penelitian lain.

\section{DAFTAR PUSTAKA}

Anasrullah, A. (2018). Nilai-Nilai Religius pada Novel Ajari Aku Menuju Arsy Karya Wahyu Sujani. Stilistika: Jurnal Pendidikan Bahasa Dan Sastra, 10(1).

Ambarwati, A., Wahyuni, S., \& Darihastining, S. (2020). Coffe, Food, and The Crisis of Indonesian Family Relationship in the Poem of Khong Guan Banquette by Joko Pinurbo. International Conference on Community Development (ICCD 2020),

Azizah, A. H. (2021). Kritik Sosial
pada Puisi dalam Buku
"Perjamuan Khong Guan"
Karya Joko Pinurbo (Analisis
Semiotik Roland Barthes)
Universitas
Soedirman].

Firdaus, D. R. (2021). Analisis Struktural Pada Kumpulan Puisi "Perjamuan Khong Guan" Karya Joko Pinurbo Sebagai Bahan Ajar Kelas X FKIP UNPAS].

Hadi W.M., A. (2014). Hermeneutika Sastra Barat dan Timur. Sadra Press. 
Johnson, B. R., Jang, S. J., Larson, D. B., \& De Li, S. (2001). Does adolescent religious commitment matter? A reexamination of the effects of religiosity on delinquency. Journal of Research in Crime and Delinquency, 38(1), 22-44.

Lie, S. (2020). Perancangan buku tipografi eksperimental (studi interpretasi: seri puisi Khong Guan karya Joko Pinurbo)= Experimental typography book design (interpretation study: Khong guan poetry series by Joko Pinurbo) Universitas Pelita Harapan].

Lutfi, M. (2007). Hermeneutika: Pemahaman Konseptual dan Metodologis. Jurnal Nasional Masyarakat, Kebudayaan dan Politik, 22, 203-207.

Mukodas, \& Mubarock, W. F. (2019). Sisi Humor dan Cita Rasa Khong Guan Pada Puisi-Puisi Joko Pinurbo. Seminar Internasional Riksa Bahasa,

Pinurbo, J. (2019). Puisi, Media Sosial, dan Partisanisme. Seminar Nasional Kabastra IV, Magelang, Indonesia.

Pinurbo, J. (2020). Perjamuan Khong Guan (SC). PT Gramedia
Pustaka Utama. https://books.google.co.id/book s?id=ibzNDwAAQBAJ

Prie, G. S. (2004). Merenung sampai mati. Tiga Serangkai. https://books.google.co.id/book $\underline{\text { s?id=KhlqpO-E7CwC }}$

Ricoeur, P. (2021). Hermeneutika dan Ilmu-ilmu Humaniora (Y. Santoso, Trans.). IRCISOD. https://books.google.co.id/book $\underline{\mathrm{s} ? \mathrm{id}=\mathrm{rgyEAAAQBAJ}}$

Rosidi, A. (2017). Cari Muatan: Empat Kumpulan Sajak. Dunia Pustaka Jaya. https://books.google.co.id/book $\underline{\mathrm{s} ? \mathrm{id}=8 \mathrm{uOIDwAAQBAJ}}$

Sugiyono. (2010). Metode Penelitian Kuantitatif, Kualitatif, dan $R \& D$. Alfabeta.

Yoko, F. (2021). Citraan Dalam Kumpulan Puisi Perjamuan Khong Guan karya Joko Pinurbo STKIP PGRI Sumatera Barat].

Zuchdi, D., \& Afifah, W. (2021). Analisis Konten Etnografi \& Grounded Theory, dan Hermeneutika Dalam Penelitian (Vol. 314). Bumi Aksara. 